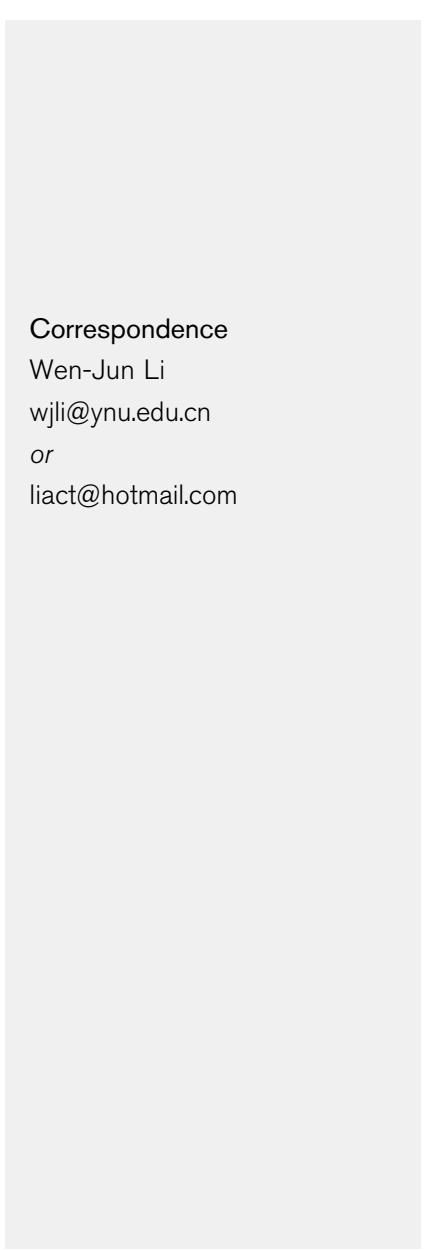

\title{
Pseudonocardia ailaonensis sp. nov., isolated from soil in China
}

\author{
Sheng Qin, ${ }^{1}$ Yun-Yun Su, ${ }^{1}$ Yu-Oin Zhang, ${ }^{1,2}$ Hai-Bin Wang, ${ }^{3}$ \\ Cheng-Lin Jiang, ${ }^{1}$ Li-Hua $\mathrm{Xu}^{1}$ and Wen-Jun $\mathrm{Li}^{1,4}$
}
${ }^{1}$ The Key Laboratory for Microbial Resources of the Ministry of Education, PR China, and Laboratory for Conservation and Utilization of Bio-resources, Yunnan Institute of Microbiology, Yunnan University, Kunming, Yunnan 650091, PR China
${ }^{2}$ Institute of Medicinal Biotechnology, Chinese Academy of Medical Sciences and Peking Union Medical College, Beijing 100050, PR China
${ }^{3}$ Center of Technology, Hisun Pharmaceutical Co. Ltd, Taizhou 318000, PR China
${ }^{4}$ Guangdong Key Laboratory of Marine Materia Medica, South China Sea Institute of Oceanology, Chinese Academy of Sciences, Guangzhou 510301, PR China

\begin{abstract}
A Gram-positive, aerobic actinomycete, designated strain YIM $45505^{\top}$, was isolated from a soil sample collected from Yunnan province, south-west China. Cells exhibited cream-white aerial mycelium and orange-yellow to yellow-brown substrate mycelium. The substrate mycelium fragmented into rod-shaped elements, and the aerial mycelium formed long chains of spores. 16S rRNA gene sequence analysis revealed that strain YIM $45505^{\top}$ was related most closely to Pseudonocardia oroxyli DSM $44984^{\top}$ (98.5\% similarity) and Pseudonocardia halophobica IMSNU $21327^{\top}$ (97.5\%). The G $+\mathrm{C}$ content of the DNA of strain YIM $45505^{\top}$ was 74.1 mol\%. Combined with results of DNA-DNA hybridization and phenotypic tests, these data revealed that strain YIM $45505^{\top}$ represents a novel species of the genus Pseudonocardia, for which the name

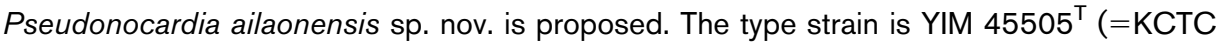
$19315^{\top}=$ DSM $44979^{\top}$ ).
\end{abstract}

The genus Pseudonocardia was erected by Henssen (1957) to accommodate nocardioform actinomycetes that have a type IV cell wall and lack mycolic acids. Its description was later emended by Warwick et al. (1994), McVeigh et al. (1994), Reichert et al. (1998) and Huang et al. (2002). At the time of writing, the genus Pseudonocardia comprises 26 recognized species, the majority of which have been described based on data from polyphasic approaches (Lee et al., 2002; Kämpfer \& Kroppenstedt, 2004; Gu et al., 2006).

During the course of our study on isolation methods of rare actinomycetes, a Pseudonocardia-like strain was isolated from a soil sample. The aim of the present study was to characterize the taxonomic position of this strain, designated YIM $45505^{\mathrm{T}}$. Genotypic and phenotypic data showed that the new isolate should be recognized as representing a novel species of the genus Pseudonocardia.

The GenBank/EMBL/DDBJ accession number for the 16S rRNA gene sequence of strain YIM $45505^{\top}$ is DQ344632.

A scanning electron micrograph of cells of strain YIM 45505' ${ }^{\top}$, an extended neighbour-joining tree based on 16S rRNA gene sequences and a table giving the fatty acid contents of strain YIM $45505^{\top}$ and related species are available as supplementary material with the online version of this paper.
Strain YIM $45505^{\mathrm{T}}$ was isolated from a soil sample collected from Ailao Mountain in Yunnan province, south-west China. The medium used for isolation was modified starchcasein agar [0.3 $\mathrm{g}$ mannose, $2 \mathrm{~g} \mathrm{KNO}_{3}, 0.3 \mathrm{~g}$ casein, $0.05 \mathrm{~g}$ $\mathrm{MgSO}_{4} .7 \mathrm{H}_{2} \mathrm{O}, 2 \mathrm{~g} \mathrm{NaCl}, 2 \mathrm{~g} \mathrm{~K} \mathrm{HPO}_{4}, 0.02 \mathrm{~g} \mathrm{CaCO}_{3}$, $10 \mathrm{mg} \mathrm{FeSO}_{4} \cdot 7 \mathrm{H}_{2} \mathrm{O}$ and $15 \mathrm{~g}$ agar in $1000 \mathrm{ml}$ tap water ( $\mathrm{pH}$ 7.2-7.4)], which was incubated at $28{ }^{\circ} \mathrm{C}$ for 2 weeks. Biomass for molecular systematic and chemotaxonomic characterization studies was obtained by cultivation in yeast extract-malt extract broth (ISP 2; Shirling \& Gottlieb, 1966) $\left(28{ }^{\circ} \mathrm{C}, 1\right.$ week, with shaking at 150 r.p.m.). Cultural characteristics of the new isolate were determined after 23 weeks at $28{ }^{\circ} \mathrm{C}$ in accordance with methods recommended by the International Streptomyces Project (ISP; Shirling \& Gottlieb, 1966). Morphological features of spores and mycelia were observed by light microscopy (Olympus microscope $\mathrm{BH}-2$ ) and scanning electron microscopy (JSM 5600LV; JEOL). Growth was tested at 0, 4, 10, 15, 20, 28, 37, 40,45 and $55{ }^{\circ} \mathrm{C}$ on ISP 2 . The ability of the strain to grow at different $\mathrm{pH}$ values $(\mathrm{pH} 5.0-10.0$, at intervals of $0.5 \mathrm{pH}$ units) and $\mathrm{NaCl}$ concentrations $(0-10 \%, \mathrm{w} / \mathrm{v}$, at intervals of $0.5 \%$ ) was examined by using ISP 2 as the basal medium. Media and procedures used for determination of physiological features and carbon source utilization were those 
described by Shirling \& Gottlieb (1966) and Smibert \& Krieg (1981). Acid production from carbohydrates was assessed by using the media and methods described by Gordon et al. (1974). Colony colour was determined in accordance with Kelly (1964).

Amino acid and sugar analysis of whole-cell hydrolysates followed standard procedures (Hasegawa et al., 1983). Phospholipids were extracted, examined by two-dimensional TLC and identified by using recognized procedures (Minnikin et al., 1979; Collins \& Jones, 1980). Menaquinones were isolated by using the method of Collins et al. (1977) and were analysed by HPLC (Groth et al., 1997). Analysis of the whole-cell fatty acid pattern followed the instructions of the MIDI System (Microbial ID) (Kroppenstedt, 1985) by using exponential phase cultures.

Genomic DNA extraction, PCR amplification and sequencing of the $16 \mathrm{~S}$ rRNA gene were performed according to $\mathrm{Li}$ et al. (2007). Multiple alignment with sequences of the most closely related actinobacteria and calculations of levels of sequence similarity were carried out by using CLUSTAL_X (Thompson et al., 1997). Neighbour-joining (Saitou \& Nei, 1987) and maximum-parsimony (Kluge \& Farris, 1969) trees were constructed by using MEGA version 3.1 (Kumar et al., 2004). Pairwise distances for the neighbour-joining algorithm were calculated with Kimura's two-parameter model (Kimura, 1980) and close-neighbour-interchange ( earch level $=2$, random additions $=100$ ) was applied in maximum-parsimony analysis. The topology of the trees was evaluated by performing a bootstrap analysis (Felsenstein, 1985) with 1000 resamplings.

The DNA G $+\mathrm{C}$ content of strain YIM $45505^{\mathrm{T}}$ was determined by using the HPLC method (Mesbah et al., 1989). DNA-DNA hybridization between strain YIM $45505^{\mathrm{T}}$ and its closest phylogenetic neighbours was carried out by using the method described by He et al. (2005).

Strain YIM $45505^{\mathrm{T}}$ developed well on most media tested, including ISP 2, ISP 5 (glycerol-asparagine agar), potato agar and Czapek's agar (Waksman, 1967). The cells produced cream-white aerial mycelium on all the media. The colour of the substrate mycelium was orange-yellow on Czapek's agar, yellow-brown on ISP 5 and deep orange-yellow on ISP 2 and potato agar media. The substrate mycelium fragmented into rod-shaped elements, and the aerial mycelium formed long chains of spores. The spores were smooth and non-motile (see Supplementary Fig. S1 in IJSEM Online). No diffusible pigments were produced on any of the media. The optimal $\mathrm{pH}$ and temperature for growth of strain YIM $45505^{\mathrm{T}}$ were about $\mathrm{pH} 7.0$ and $28{ }^{\circ} \mathrm{C}$. Detailed physiological and biochemical properties of strain YIM $45505^{\mathrm{T}}$ are provided in the species description. A comparison of the physiological properties of strain YIM $45505^{\mathrm{T}}$, Pseudonocardia oroxyli DSM $44984^{\mathrm{T}}$ and Pseudonocardia halophobica IMSNU $21327^{\mathrm{T}}$ is given in Table 1.

Whole-organism hydrolysates of strain YIM $45505^{\mathrm{T}}$ were rich in meso-diaminopimelic acid, arabinose, ribose,
Table 1. Comparison of the physiological characteristics of strain YIM $45505^{\top}$ and the type strains of the two most closely related Pseudonocardia species

Strains: 1 , YIM $45505^{\mathrm{T}} ; 2$, P. oroxyli DSM $44984^{\mathrm{T}} ; 3$, P. halophobica IMSNU $21327^{\mathrm{T}}$. + , Positive; - , negative; $(+)$, weakly positive. Data were obtained in this study. All strains are positive for acid production from D-fructose, D-galactose, D-glucose, glycerol, maltose, D-mannitol, $\mathrm{D}$-mannose, sucrose and trehalose, but negative for acid production from cellobiose, methyl $\alpha$-D-glucoside, D-lactose, D-lactulose, raffinose and salicin. All strains are positive for assimilation of L-arabinose, citrate, dulcitol, D-fructose, D-glucose, glycerol, glycogen, D-mannose, L-methionine, L-phenylalanine, L-proline, raffinose, trehalose and Lvaline, but negative for assimilation of L-leucinamide.

\begin{tabular}{|c|c|c|c|}
\hline Characteristic & 1 & 2 & 3 \\
\hline \multicolumn{4}{|c|}{ Acid production from: } \\
\hline L-Arabinose & - & - & + \\
\hline Dulcitol & $(+)$ & - & + \\
\hline Erythritol & - & - & + \\
\hline Inositol & - & - & + \\
\hline Melezitose & - & + & + \\
\hline D-Sorbitol & - & - & + \\
\hline D-Sorbose & - & - & + \\
\hline D-Xylose & + & - & $(+)$ \\
\hline \multicolumn{4}{|c|}{ Assimilation of sole carbon sources } \\
\hline Acetate & - & + & + \\
\hline Cellobiose ${ }^{*}$ & + & $(+)$ & $(+)$ \\
\hline D-Galactose ${ }^{*}$ & - & $(+)$ & - \\
\hline Inositol & + & + & - \\
\hline D-Lactose ${ }^{*}$ & + & $(+)$ & $(+)$ \\
\hline D-Mannitol & + & + & - \\
\hline Melezitose & $(+)$ & + & - \\
\hline Oxalate & $(+)$ & $(+)$ & - \\
\hline D-Rhamnose* & + & $(+)$ & $(+)$ \\
\hline D-Ribose ${ }^{*}$ & + & + & $(+)$ \\
\hline Salicin & $(+)$ & $(+)$ & - \\
\hline D-Sorbitol & + & + & - \\
\hline Sucrose & + & + & - \\
\hline D-Xylose $e^{*}$ & - & + & $(+)$ \\
\hline \multicolumn{4}{|c|}{ Assimilation of sole nitrogen sources } \\
\hline L-Arginine & + & - & + \\
\hline L-Cysteine & + & - & $(+)$ \\
\hline L-Ornithine & + & + & $(+)$ \\
\hline L-Threonine & + & - & + \\
\hline L-Tyrosine $e^{\star}$ & + & - & + \\
\hline \multicolumn{4}{|c|}{ Decomposition of: } \\
\hline Adenine & - & + & $(+)$ \\
\hline Hypoxanthine & + & + & $(+)$ \\
\hline L-Tyrosine & + & + & $(+)$ \\
\hline Xanthine & $(+)$ & + & + \\
\hline \multicolumn{4}{|c|}{ Growth in the presence of: } \\
\hline $5 \% \mathrm{NaCl}$ & + & + & $(+)$ \\
\hline $7 \% \mathrm{NaCl}$ & - & $(+)$ & $(+)$ \\
\hline
\end{tabular}

${ }^{\star}$ Tests on P. oroxyli and P. halophobica were also carried out by Gu et al. (2006) and gave congruent results. 


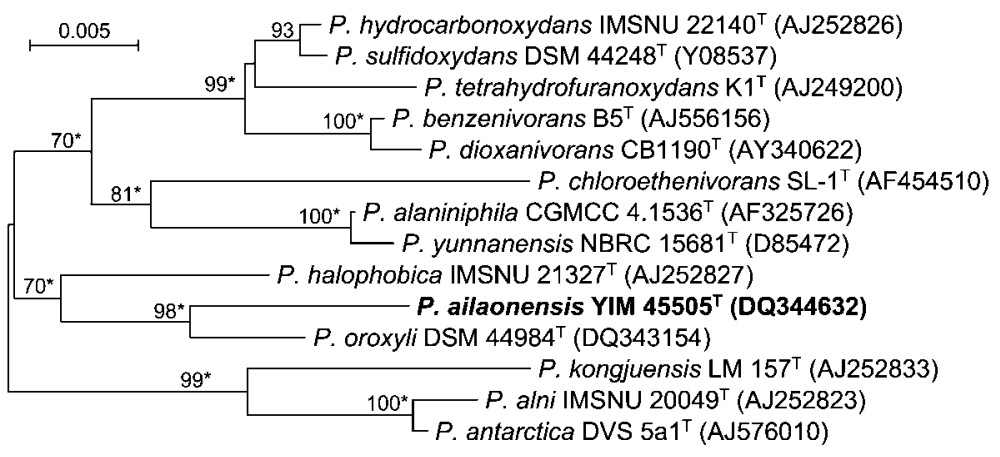

Fig. 1. Neighbour-joining phylogenetic tree based on 16S rRNA gene sequences showing relationships between strain YIM $45505^{\top}$ and related representatives of Pseudonocardia species. Asterisks indicate branches that were conserved in both the neighbour-joining and maximum-parsimony trees. Bootstrap values at branch points are expressed as percentages from 1000 replications (only values greater than $50 \%$ are indicated). Bar, $0.5 \%$ sequence divergence. An extended version of this tree is available as Supplementary Fig. S1.

galactose and glucose. The predominant menaquinone was MK-8 $\left(\mathrm{H}_{4}\right)$. Cells of strain YIM $45505^{\mathrm{T}}$ had a type PIII phospholipid pattern (Lechevalier et al., 1977). Major phospholipids were diphosphatidylglycerol, phosphatidylglycerol and phosphatidylinositol. The whole-cell fatty acid profile of strain YIM $45505^{\mathrm{T}}$ mainly consisted of iso- $\mathrm{C}_{16: 0}$ (35.5\%), iso- $\mathrm{C}_{16: 0} 2-\mathrm{OH}(10.8 \%)$ and $\mathrm{C}_{16: 0} 10$-methyl $(9.0 \%)$. A comparison of the fatty acid profiles of strain YIM $45505^{\mathrm{T}}$, P. oroxyli DSM $44984^{\mathrm{T}}$ and P. halophobica IMSNU $21327^{\mathrm{T}}$ is given in Supplementary Table S1.

The almost-complete sequence of the 16S rRNA gene of strain YIM $45505^{\mathrm{T}}$ (1467 bp) was used for phylogenetic analysis. A neighbour-joining tree (Supplementary Fig. S2) based on available 16S rRNA gene sequences of the type strains of recognized Pseudonocardia species confirmed the placement of strain YIM $45505^{\mathrm{T}}$ in the genus Pseudonocardia. Strain YIM $45505^{\mathrm{T}}$ exhibited 98.5 and $97.5 \% 16 \mathrm{~S}$ rRNA gene sequence similarity to its closest neighbours, $P$. oroxyli DSM $44984^{\mathrm{T}}$ and $P$. halophobica IMSNU $21327^{\mathrm{T}}$, respectively, and these formed a distinct subclade separate from other representatives of the genus Pseudonocardia (Fig. 1 and Supplementary Fig. S2). Levels of 16S rRNA gene sequence similarity between strain YIM $45505^{\mathrm{T}}$ and the type strains of other recognized species of the genus Pseudonocardia were below $97 \%$. Strain YIM $45505^{\mathrm{T}}$ showed relatively low levels of DNA-DNA relatedness with $P$. oroxyli DSM $44984^{\mathrm{T}}(44.3 \pm 5.4 \%)$ and $P$. halophobica IMSNU $21327^{\mathrm{T}}(33.8 \pm 2.9 \%)$, which are much lower than the recommended threshold value of $70 \%$ for the delineation of genomic species (Stackebrandt \& Goebel, 1994). This clearly indicated that strain YIM $45505^{\mathrm{T}}$ represented a genomic species separate from $P$. oroxyli and P. halophobica.

Therefore, based on its phenotypic and genotypic properties, strain YIM $45505^{\mathrm{T}}$ is considered to represent a novel species of the genus Pseudonocardia, for which the name Pseudonocardia ailaonensis sp. nov. is proposed.

\section{Description of Pseudonocardia ailaonensis sp. nov.}

Pseudonocardia ailaonensis (ai.lao.nen'sis. N.L. fem. adj. ailaonensis pertaining to Ailao Mountain, Yunnan province, China, the source of the soil sample from which the type strain was isolated).

Cells are Gram-positive and aerobic. Forms cream-white aerial mycelium and orange-yellow to yellow-brown substrate mycelium on ISP 2, ISP 5, potato agar and Czapek's agar. Both substrate and aerial mycelia fragment into rodshaped elements. No pigment is produced. The temperature range for growth is $15-37{ }^{\circ} \mathrm{C}$, with optimal growth at $28{ }^{\circ} \mathrm{C}$. The $\mathrm{pH}$ range for growth is $6.0-8.0$. The $\mathrm{NaCl}$ concentration range for growth is $0-5 \%(\mathrm{w} / \mathrm{v})$. Positive for urease, catalase, melanin production (ISP 6 medium; peptone-yeast extractiron agar), nitrate reduction, milk coagulation and milk peptonization, but negative for gelatin liquefaction, hydrolysis of cellulose and starch and production of $\mathrm{H}_{2} \mathrm{~S}$. The cell wall contains meso-diaminopimelic acid. The whole-cell sugar pattern consists of arabinose, ribose, glucose and galactose. MK- $8\left(\mathrm{H}_{4}\right)$ is the predominant menaquinone. The phospholipids are diphosphatidylglycerol, phosphatidylglycerol and phosphatidylinositol (type PIII phospholipid). The major cellular fatty acid is iso- $\mathrm{C}_{16: 0}(35.5 \%)$. The $\mathrm{G}+\mathrm{C}$ content of the genomic DNA of the type strain is $74.1 \mathrm{~mol} \%$. Physiological properties, including acid production, carbon source utilization, biodegradation and growth in the presence of sodium chloride, are given in Table 1.

The type strain, YIM $45505^{\mathrm{T}}\left(=\mathrm{KCTC} 19315^{\mathrm{T}}=\mathrm{DSM}\right.$ $44979^{\mathrm{T}}$ ), was isolated from a soil in Yunnan province, south-west China.

\section{Acknowledgements}

We are grateful to Dr Jean Euzéby for his help with nomenclature. This research was supported by the National Basic Research Program of China (project no. 2004CB719601), the National Natural Science Foundation of China (project nos 30560001 and 30600001) and the Key Project of the Chinese Ministry of Education (no. 206139). W.-J. L. was supported by the Program for New Century Excellent Talents in University.

\section{References}

Collins, M. D. \& Jones, D. (1980). Lipids in the classification and identification of coryneform bacteria containing peptidoglycan based on 2, 4-diaminobutyric acid. J Appl Bacteriol 48, 459-470. 
Collins, M. D., Pirouz, T., Goodfellow, M. \& Minnikin, D. E. (1977) Distribution of menaquinones in actinomycetes and corynebacteria. J Gen Microbiol 100, 221-230.

Felsenstein, J. (1985). Confidence limits on phylogenies: an approach using the bootstrap. Evolution 39, 783-791.

Gordon, R. E., Barnett, D. A., Handerhan, J. E. \& Pang, C. H.-N. (1974). Nocardia coeliaca, Nocardia autotrophica, and the nocardin strain. Int J Syst Bacteriol 24, 54-63.

Groth, I., Schumann, P., Rainey, F. A., Martin, K., Schuetze, B. \& Augsten, K. (1997). Demetria terragena gen. nov., sp. nov., a new genus of actinomycetes isolated from compost soil. Int J Syst Bacteriol 47, 1129-1133.

Gu, Q., Luo, H., Zheng, W., Liu, Z. \& Huang, Y. (2006). Pseudonocardia oroxyli sp. nov., a novel actinomycete isolated from surfacesterilized Oroxylum indicum root. Int J Syst Evol Microbiol 56, 2193-2197.

Hasegawa, T., Takizawa, M. \& Tanida, S. (1983). A rapid analysis for chemical grouping of aerobic actinomycetes. J Gen Appl Microbiol 29, 319-322.

He, L., Li, W., Huang, Y., Wang, L., Liu, Z., Lanoot, B., Vancanneyt, M. \& Swings, J. (2005). Streptomyces jietaisiensis sp. nov., isolated from soil in northern China. Int J Syst Evol Microbiol 55, 1939-1944.

Henssen, A. (1957). Beiträge zur Morphologie und Systematik der thermophilen Actinomyceten. Arch Mikrobiol 26, 373-414 (in German).

Huang, Y., Wang, L., Lu, Z., Hong, L., Liu, Z., Tan, G. Y. A. \& Goodfellow, M. (2002). Proposal to combine the genera Actinobispora and Pseudonocardia in an emended genus Pseudonocardia, and description of Pseudonocardia zijingensis sp. nov. Int J Syst Evol Microbiol 52, 977-982.

Kämpfer, P. \& Kroppenstedt, R. M. (2004). Pseudonocardia benzenivorans sp. nov. Int J Syst Evol Microbiol 54, 749-751.

Kelly, K. L. (1964). Inter-Society Color Council - National Bureau of Standards Color Name Charts Illustrated with Centroid Colors. Washington, DC: US Government Printing Office.

Kimura, M. (1980). A simple method for estimating evolutionary rates of base substitutions through comparative studies of nucleotide sequences. J Mol Evol 16, 111-120.

Kluge, A. G. \& Farris, F. S. (1969). Quantitative phyletics and the evolution of anurans. Syst Zool 18, 1-32.

Kroppenstedt, R. M. (1985). Fatty acid and menaquinone analysis of actinomycetes and related organisms. In Chemical Methods in Bacterial Systematics (Society for Applied Bacteriology Technical Series vol. 20), pp. 173-199. Edited by M. Goodfellow \& D. E. Minnikin. New York: Academic Press.

Kumar, S., Tamura, K. \& Nei, M. (2004). MEGA3: integrated software for molecular evolutionary genetics analysis and sequence alignment. Brief Bioinform 5, 150-163.
Lechevalier, M. P., De Bièvre, C. \& Lechevalier, H. A. (1977). Chemotaxonomy of aerobic actinomycetes: phospholipid composition. Biochem Syst Ecol 5, 249-260.

Lee, S. D., Kim, E. S., Kang, S.-O. \& Hah, Y. C. (2002). Pseudonocardia spinosispora sp. nov., isolated from Korean soil. Int $J$ Syst Evol Microbiol 52, 1603-1608.

Li, W. J., Xu, P., Schumann, P., Zhang, Y. Q., Pukall, R., Xu, L. H., Stackebrandt, E. \& Jiang, C. L. (2007). Georgenia ruanii sp. nov., a novel actinobacterium isolated from forest soil in Yunnan (China) and emended description of the genus Georgenia. Int J Syst Evol Microbiol 57, 1424-1428.

McVeigh, H. P., Munro, J. \& Embley, T. M. (1994). The phylogenetic position of Pseudoamycolata halophobica (Akimov et al. 1989) and a proposal to reclassify it as Pseudonocardia halophobica. Int J Syst Bacteriol 44, 300-302.

Mesbah, M., Premachandran, U. \& Whitman, W. B. (1989). Precise measurement of the $\mathrm{G}+\mathrm{C}$ content of deoxyribonucleic acid by highperformance liquid chromatography. Int J Syst Bacteriol 39, 159-167.

Minnikin, D. E., Collins, M. D. \& Goodfellow, M. (1979). Fatty acid and polar lipid composition in the classification of Cellulomonas, Oerskovia and related taxa. J Appl Bacteriol 47, 87-95.

Reichert, K., Lipski, A., Pradella, S., Stackebrandt, E. \& Altendorf, K. (1998). Pseudonocardia asaccharolytica sp. nov. and Pseudonocardia sulfidoxydans sp. nov., two new dimethyl disulfide-degrading actinomycetes and emended description of the genus Pseudonocardia. Int J Syst Bacteriol 48, 441-449.

Saitou, N. \& Nei, M. (1987). The neighbor-joining method: a new method for reconstructing phylogenetic trees. Mol Biol Evol 4, 406-425.

Shirling, E. B. \& Gottlieb, D. (1966). Methods for characterization of Streptomyces species. Int J Syst Bacteriol 16, 313-340.

Smibert, R. M. \& Krieg, N. R. (1981). General characterization. In Manual of Methods for General Microbiology, pp. 409-443. Edited by P. Gerhardt, R. G. E. Murray, R. N. Costilow, E. W. Nester, W. A. Wood, N. R. Krieg \& G. B. Phillips. Washington, DC: American Society for Microbiology.

Stackebrandt, E. \& Goebel, B. M. (1994). Taxonomic note: a place for DNA-DNA reassociation and $16 \mathrm{~S}$ rRNA sequence analysis in the present species definition in bacteriology. Int J Syst Bacteriol 44, 846-849.

Thompson, J. D., Gibson, T. J., Plewniak, F., Jeanmougin, F. \& Higgins, D. G. (1997). The CLUSTAL_X windows interface: flexible strategies for multiple sequence alignment aided by quality analysis tools. Nucleic Acids Res 25, 4876-4882.

Waksman, S. A. (1967). The Actinomycetes. A Summary of Current Knowledge. New York: Ronald Press.

Warwick, S., Bowen, T., McVeigh, H. P. \& Embley, T. M. (1994). A phylogenetic analysis of the family Pseudonocardiaceae and the genera Actinokineospora and Saccharothrix with 16S rRNA sequences and a proposal to combine the genera Amycolata and Pseudonocardia in an emended genus Pseudonocardia. Int J Syst Bacteriol 44, 293-299. 